Article

\title{
Invasion of the European River Lamprey Lampetra fluviatilis in the Upper Volga
}

\author{
Aleksandr O. Zvezdin (D, Aleksandr V. Kucheryavyy *D, Anzhelika V. Kolotei, Natalia V. Polyakova \\ and Dmitry S. Pavlov
}

check for updates

Citation: Zvezdin, A.O.; Kucheryavyy, A.V.; Kolotei, A.V.; Polyakova, N.V.; Pavlov, D.S. Invasion of the European River Lamprey Lampetra fluviatilis in the Upper Volga. Water 2021, 13, 1825. https://doi.org/10.3390/w13131825

Academic Editors: Lyudmila

Kamnurska, Agnese Marchini and Hugh MacIsaac

Received: 27 May 2021

Accepted: 27 June 2021

Published: 30 June 2021

Publisher's Note: MDPI stays neutral with regard to jurisdictional claims in published maps and institutional affiliations.

Copyright: (c) 2021 by the authors. Licensee MDPI, Basel, Switzerland. This article is an open access article distributed under the terms and conditions of the Creative Commons Attribution (CC BY) license (https:// creativecommons.org/licenses/by/ $4.0 /)$.
Institute of Ecology and Evolution, Russian Academy of Sciences, 119071 Moscow, Russia; a.o.zvezdin@gmail.com (A.O.Z.); anjee1227@gmail.com (A.V.K.); nvpnataly@yandex.ru (N.V.P.); acad.pavlov@gmail.com (D.S.P.)

* Correspondence: scolopendra@bk.ru

\begin{abstract}
The European river lamprey came to the Upper Volga from the Baltic Sea most probably via a system of shipways developed in the 18th and 19th centuries. The Vyshnii Volochek, Tikhvin, and Mariinskaya water systems are possible invasion pathways for this species. Dispersal and colonization of the Caspian Basin was likely a combination of upstream and downstream migrations. Analysis of museum and our own samples showed that lamprey possibly migrated upstream (for spawning) along rivers of the Baltic Basin until they reached the watershed boundary from which they could disperse downstream (in the juvenile period) into rivers of the Caspian Basin. Dispersal in the Volga River could occur in accordance with the migration cycle of this opportunistic lamprey species and lead to the present distribution. Key features (dentition and number of trunk myomeres) showed that lamprey from the studied area are similar to lampreys from the Baltic basin, although specimens in each population have their own peculiarities in morphology (size and coloration). Genetic data (Cyt-b) support the idea of a relatively recent invasion of lamprey into the Upper Volga. The haplotype, found in three rivers, is one of the most widespread in Europe and is found along the supposed route of invasion.
\end{abstract}

Keywords: Petromyzontidae; behavior; invasion; distribution; downstream migration; upstream migration

\section{Introduction}

Four genera of lamprey (Petromyzontiformes) occur in the central part of Eastern Europe (European part of Russia, Figure 1). Representatives of the genera Lampetra (the Northeast Atlantic Ocean and the rivers of Europe) and Lethenteron (drainages of the White and Barents seas of the Arctic Ocean) are represented by both migrant (anadromous and potamodromous) and freshwater (the so-called resident) ecological forms. The genus Caspiomyzon (the Caspian Sea and the rivers of its northern, western, and southern watersheds) includes only anadromous lampreys, while the genus Eudontomyzon (rivers of the Black and Azov seas) currently includes only freshwater forms [1-8].

Before the construction of the Volga Hydroelectric Station (1958), the Volga River system was almost entirely populated by the Caspian lamprey, Caspiomyzon wagneri, an anadromous species that does not form freshwater populations or satellite (paired) freshwater species if impounded [7,9]. Historically, lamprey traveled up the Volga as far as the city of Kalinin (now Tver) and the mouth of the Tvertsa River [10]. These migration routes were later obstructed by the dams in the Upper Volga (the section of the Volga between the source and the confluence with the Oka River) and then blocked entirely after the construction of the Volga Hydroelectric Station. Only single specimens of the Caspian lamprey were documented upstream of the Station's dam, in the Volgograd Reservoir [11], and were absent further upstream in the Saratov Reservoir [12]. The ecological niches vacated by the Caspian lamprey "attracted" representatives of other lamprey genera: Lampetra from 
the Baltic Sea Basin and Eudontomyzon from the Azov-Black Sea Basin [4,13]. Colonization by these species became possible via anthropogenic modifications to the river network in the form of shipway construction. These modifications continued for more than three centuries, resulting in connections between the basins of five seas: the White Sea, Baltic Sea, Caspian Sea, Black Sea, and the Sea of Azov.

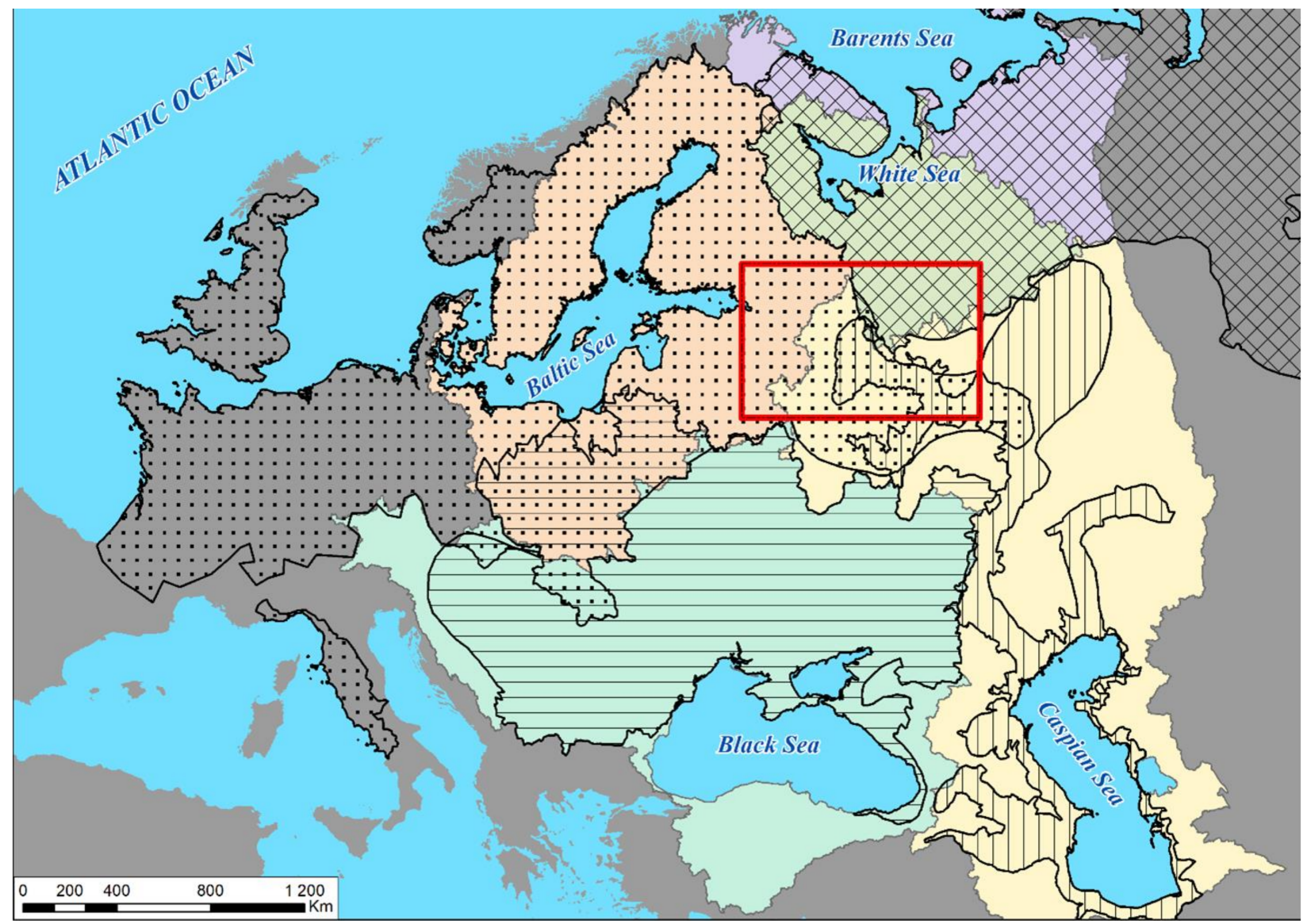

Figure 1. Study area (red square), including the watersheds of the Baltic $(\square)$, Caspian ( $\quad$ ), White ( $\square$ ), Azov-Black $(-$ ), and Barents $(\square)$ seas. The coastline is based on SHP small-scale data [14]. Basins are based on [15]. Distribution of the European river lamprey Lampetra fluviatilis $(\because)$, Caspian lamprey Caspiomyzon wagneri (ITा), Arctic lamprey Lethenteron

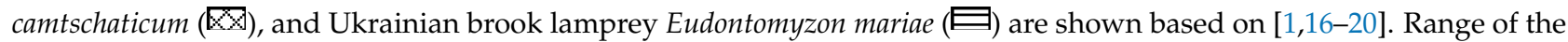
Caspian lamprey is shown as it was before dam cascade construction (1933-1980) on the Volga River.

The anadromous form of the European river lamprey, Lampetra fluviatilis, inhabits the basins of the North, Baltic, and Mediterranean Seas. The freshwater form of the European river lamprey, traditionally referred to as the European brook lamprey, Lampetra planeri, has been documented repeatedly in the Upper Volga, i.e., in the Caspian Sea Basin in the mid- and late 20th century [10,21-27]. Earlier information about lampreys in this area was not found, since small forms were not of interest in the 18-19th centuries, and the modern taxonomic statuses were established only by the beginning of the 20th century, when the genus Caspiomyzon was distinguished among other genera.

There are reasons to believe that the invasion of the European river lamprey into the Volga River was associated with the development of inland shipping and the network of shipways in the 18th-19th centuries. Therefore, the Upper Volga is of special interest for studies dealing with the dispersal of various aquatic organisms (hydrobionts). It is connected with rivers of the Baltic Sea Basin by three hydrological systems of shipways, and with rivers of the White Sea Basin by one hydrological system. Two navigable waterways from the Baltic Sea and one from the White Sea connect with the Rybinsk Reservoir, which 
is the zone of "accumulation of invaders" as well as the area of intergradation of northern and the Ponto-Caspian aquatic organisms [28].

The freshwater form of the European river lamprey is currently included in the fish fauna species lists of the Rybinsk Reservoir with a status as a rare species, decreasing in numbers [28-30]. Some researchers noted that the lamprey does not occur in the reservoir itself [28], surviving as small local populations in the tributaries [30]. Other experts question the presence of the European river lamprey in the Rybinsk Reservoir [31,32]. However, to date there is no detailed information on the distribution of the European river lamprey in the Rybinsk Reservoir and in the Upper Volga in general. Moreover, morphological characteristics of specimens from these local populations are also unknown.

Invasions can be caused by both natural processes and anthropogenic influence, and their control is not possible without the integration of local, regional, and global data. A comprehensive study of such a large invasion corridor as the Volga has been carried out for a long time, but the study of lamprey populations and the pulsation of their ranges has practically never been paid attention to. Understanding the basic problems of distribution and biology is necessary, in our opinion, for solving many issues related to the conservation and management of species. This work is aimed at determining whether representatives of the order Petromyzontiformes occur in the rivers of the Upper Volga Basin in the present, and to analyze invasion pathways and dispersal mechanisms of lamprey from their historical range to the Upper Volga Basin.

\section{Material and Methods}

\subsection{Study Area and Habitats}

This study was based on an analysis of our own collected material: collections of lamprey larvae and spawning adults as well as observations on the distribution of lamprey in the Upper Volga (central European Russia, Figure 1). This research resulted in investigation of 30 rivers, with a total of 241 site surveys to find lamprey, of which 43 surveys were successful. The investigated areas of the Tikhvin and Mariinskaya water systems included 13 sites (Rivitsa, Keza, Sunoga, Shumarovka, Latka, Chesnava, Sutka, Sebla, Ild, Gremyshka, Myshkovka, Tunoshonka, and Kisma) in which no lamprey were documented, but six sites (Tunoshonka, Kamenka, Saragozha, Volchina, and Vysochinsly and its tributary) that were inhabited by lamprey. We investigated four sites in the Vyshnevolotskaya water system (Bolshaya Dubenka, Cheremnitsa, Shchapovsky, and Gorokhovets), where zero lamprey were found, and seven sites (Malaya Dubenka, Malaya Kosha, Bolshaya Kosha, Vyazma, Bolshaya Sestra, Yakhroma, and Shutinka) where lamprey were found (Figure 2).

The Vysochinsky Stream and its unnamed tributary are, respectively, the fifth- and the sixth-order tributaries of the Rybinsk Reservoir. These streams connect with the reservoir through Lake Kremino and the rivers Kremennitsa, Saragozha, and Mologa. The Vysochinsky Stream is $12.3 \mathrm{~km}$ long, while its unnamed tributary is $8.3 \mathrm{~km}$ long. Both begin in boggy areas. The Vysochinsky Stream was $5 \mathrm{~m}$ wide; its tributary was $1-2 \mathrm{~m}$ wide, and their depth was 10-30 cm. The substrate is pebbly gravel with a little sand and few rocks up to $30-40 \mathrm{~cm}$ in diameter. Upstream and downstream from the spawning area the bottom is clay-covered, with organic debris. Silty grounds suitable for the lamprey larvae were nearly absent. The water in the stream was clear and the water temperature at the spawning site at the time of this study was $11^{\circ} \mathrm{C}$. 


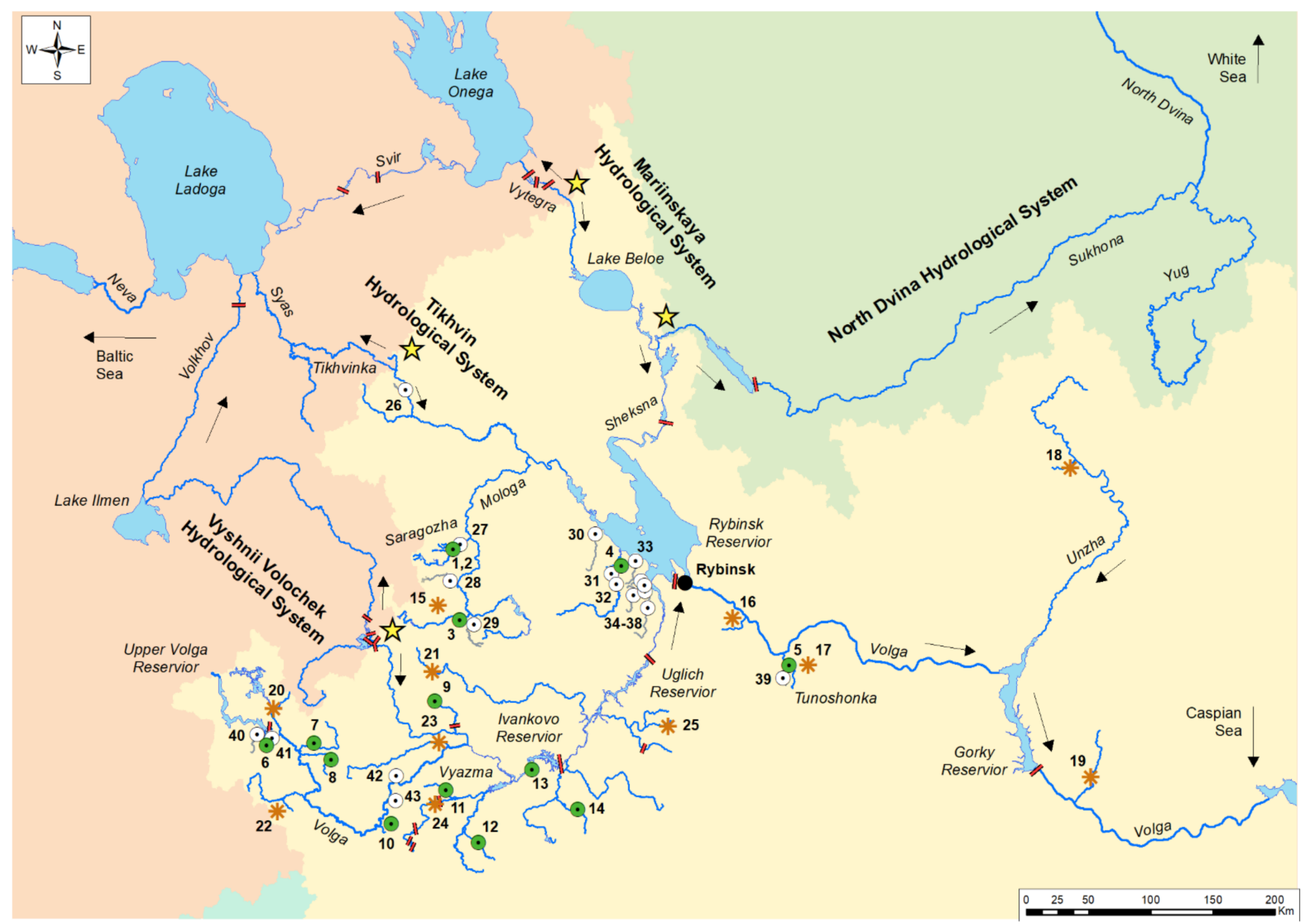

Figure 2. Generalized map of the study area and survey sites. Own sampling and observation sites ( $\odot)$ : Vysochinsky Stream and its unnamed tributary (1); Saragozha River (2), Volchina River (3), Kamenka River (4), Tunoshonka River (5), Malaya Dubenka River (6), Bolshaya Kosha River (7), Malaya Kosha River (8), Shutinka Stream (9), Kava River (10), Vyazma River (11), Bolshaya Sestra River (12), Volga River (13), and Yakhroma River (14). Distribution of the Europea river lamprey in the Upper Volga basin according to the literature (**): Serednitsa River [26] (15), Pechegda River (16), Tunoshonka River [21] (17), Vonyukh River [33] (18), Linda River [4] (19), Krapivenka River [27] (20), Medveditsa River [26] (21), Dubenka River [27] (22), Tma River [26,27] (23), Shosha River [22] (24), and Kis'ma River [21] (25). Own surveys in the rivers with no lampreys found (๔): Zagolodenka River (26), Kremennitsa River (27), Keza River (28), Rivitsa River (29), Sebla River (30), Myshkovka River (31), Gremyshka River (32), Chesnava River (33), Latka River (34), Sunoga River (35), Shumarovka River (36), Ild River (37), Sutka River (38), Kisma River (39), Bolshaya Dubenka River (40), Cheremnitsa River (41), Ogorohovitsa River (42), and Schapovskyy Creek (43). Basins and boundaries: Baltic ( $\square$ ), Caspian ( ), White $(\square)$, and Azov-Black Sea $(\square)$; watershed boundaries of the basins $(\star)$ and dams ( $\square)$.

The Saragozha River is a second-order tributary of the Rybinsk Reservoir. It flows from Lake Pavlovskoe and is $53 \mathrm{~km}$ long. Along with the Vysochinsky Stream, the Saragozha belongs to a vast fluvio-lacustrine system, which also includes Lake Ilovets, the Ilovets River, Lake Zastizhskoe, Lake Obretinskoe, the Zhelezinka River, etc. The width of the surveyed section of the river was $\sim 15 \mathrm{~m}$, and the depth was $0.5-1 \mathrm{~m}$, with pools up to $2 \mathrm{~m}$ deep. The bottom was sandy, with occasional small pebbly areas. It was in these pebbly areas that the lampreys were observed spawning. The water had a light brownish (peaty) color and the water temperature was $12{ }^{\circ} \mathrm{C}$ at the time of sampling.

The Volchina River (106 km long) is a second-order tributary of the Rybinsk Reservoir. A 200-m part of the lower reaches of the river was investigated. The width of the river was 60-70 $\mathrm{m}$, with an island (88 $\mathrm{m}$ long and 10-15 $\mathrm{m}$ width) in the middle of the stretch. The depth varied between 1 and $2.5 \mathrm{~m}$. The bottom and the sides of the river were sandy, with 
pebbles in some places. In the bays along the banks of the river and those of the island were accumulations of debris. The water temperature was not measured.

The Kamenka River is the second-order tributary of the Rybinsk Reservoir. Its length is $14 \mathrm{~km}$. The Kamenka River is a tributary of a large river, the Sit, into which it flows at a point $13 \mathrm{~km}$ from the reservoir. We surveyed a 2-km-long section of this river, situated at a distance of $1.25 \mathrm{~km}$ from the river mouth. At this location, the river was 10-12 $\mathrm{m}$ wide and depth varied from $30 \mathrm{~cm}$ to $1.8 \mathrm{~m}$. The bottom was pebbly gravel, with numerous ratchels and boulders. Small and shallow accumulations of fallen leaves were noted in some places. The water had a light brownish (peaty) color and the water temperature was $17^{\circ} \mathrm{C}$ at the time of mature adults sampling.

The Tunoshonka River (51 km long) is a first-order tributary of the Volga River (Gorky Reservoir). It was surveyed in the lower reaches, where it was $30 \mathrm{~m}$ wide or even wider. Shallow areas with a depth of $20-50 \mathrm{~cm}$ alternated with deeper pools $(\geq 2 \mathrm{~m})$. The substrate was silty-sandy, with middle-sized pebbles in some places. The Vyazma River, which is a second-order tributary of the Volga River (Ivankovo Reservoir), is $43 \mathrm{~km}$ long. Near its mouth, the Vyazma was 5-10 m wide and 20-50 cm deep. The bottom was smooth and stony. The Malaya Dubenka River (14 km long) drains into the Upper Volga Reservoir (Lake Volgo). The lowermost 2-2.5 km of the river is a bay in the lake with no current, silty substrate, and abundant aquatic vegetation. Lamprey larvae were caught in the middle section where there was a sandy/pebble substrate, $0.5 \mathrm{~m}$ water depth, and channel width of $\sim 5 \mathrm{~m}$.

The Bolshaya Sestra River (55 km long) is a third-order tributary of the Volga River (it flows into the Ivankovo Reservoir). The width of the surveyed part of the river was $4-8 \mathrm{~m}$. Deep pools $(>2 \mathrm{~m})$ alternated with shallow areas $(0.15-0.35 \mathrm{~m})$. The bottom of the pools was covered with sand and silt, and the shallow parts were pebble and stony with sand bars. The river was rich with medium- and large-sized man-made debris. The debris and most of the stones were colonized with small algae; the water was transparent. Water temperature was not measured.

\subsection{Animals Survey and Collection}

All animals were captured and taken from the environment in accordance with guidelines approved by the Institute of Ecology and Evolution, Russian Academy of Sciences. Lamprey larvae in all rivers were caught in shallow areas with a dip net (8-mm rebar frame $50 \mathrm{~cm} \times 70 \mathrm{~cm}$ with a knotless del of $80 \mathrm{~cm}$ depth, mesh size of $2.5 \mathrm{~mm}$ ). Captured lamprey were anesthetized with an MS-222 solution ( $50 \mathrm{mg} / \mathrm{L}$ ), photographed, and placed in $96 \%$ alcohol or a $4 \%$ isotonic solution of formaldehyde. These specimens were archived in the collection of the Laboratory for Behavior of Lower Vertebrates at the Institute of Ecology and Evolution (Table 1). Data from the fish collection of the Zoological Institute of the Russian Academy of Sciences (St Petersburg, ZISP) were also used.

Lamprey spawning was documented in the Vysochinsky Stream and its tributary, in the Saragozha River on 15 May 2019, and in the Kamenka River on 15 May 2018 (Figure 2). Collections and observations of lamprey larvae were made in the Tunoshonka River on 5 July 2014, in the Vyazma River on 13 June 2014, in the Malaya Dubenka River on 30 June 2020, and in the Volchina River on 2 September, According to communications of the researchers from the Laboratory for Behaviour of Lower Vertebrates of A.N. Severtsov Institute of Ecology and Evolution (B.P. Legky, D.Yu. Nazarov, M.P. Ostrovsky, I.K. Popova, E.A Kirillova, and P.I. Kirillov), adults of the resident form of the European river lamprey were observed to spawn in different years in the Shutinka Stream, the Malaya Kosha River, the Bolshaya Kosha River, and the Kava River, which are the tributaries of various orders of the Volga in the upper reaches. A resident adult was also caught in the Volga near the town of Konakovo. 
Table 1. Samples, used in the paper, and their characteristics.

\begin{tabular}{ccccc}
\hline Sample ID & Locality & Collection Date & Life Stage & Sample Size \\
\hline IEE 19051501 & Vysochinsky & 15 May 2019 & adult & 30 \\
IEE 19051502 & Saragozha & 15 May 2019 & adult & 7 \\
IEE 20090201 & Volchina & 2 September 2020 & ammocoete & 1 \\
IEE 20090202 & Volchina & 2 September 2020 & ammocoete & 6 \\
IEE 18051501 & Kamenka & 15 May 2018 & adult & 5 \\
IEE 17082301 & Kamenka & 23 August 2017 & ammocoete & 8 \\
IEE 14070501 & Tunoshonka & 5 July 2014 & ammocoete & 5 \\
IEE 20063001 & Malaya Dubenka & 30 June 2020 & ammocoete & 29 \\
IEE 20063002 & Malaya Dubenka & 30 June 2020 & ammocoete & 5 \\
IEE 12073001 & Malaya Kosha & 30 July 2012 & ammocoete & 20 \\
IEE 13051201 & Bolshaya Kosha & 12 May 2013 & ammocoete & 69 \\
IEE 13051202 & Bolshaya Kosha & 12 May 2013 & adult & 1 \\
IEE 14051802 & Kava & 18 May 2014 & adult & 2 \\
IEE 13070002 & Volga & July 2013 & adult & 1 \\
IEE 14051601 & Bolshaya Sestra & 16 May 2014 & adult & 14 \\
IEE 14051702 & Bolshaya Sestra & 17 May 2014 & ammocoete & 4 \\
IEE 14051703 & Bolshaya Sestra & 17 May 2014 & adult & 1 \\
\hline
\end{tabular}

\subsection{Cartography, Meta- and Digital Data}

The distances of the water bodies of the Baltic Basin and the tributaries of the Upper Volga provided in this paper were measured based on satellite images or topographic maps and are as accurate as possible. In the few instances when the distances were taken from the literature, references are provided.

The coastline depicted in the figures in this paper was based on SHP small-scale data [14]. The marine basins layer was developed using the Hydrosheds database [34] and the Interactive database of the world's river basins [15], and the water features were established using the HydroSheds database [35] by analyzing the topographic maps and satellite imagery of Google Maps and Google Earth. Species distributions outlined on [1,16-20]. A historical map representing the state of the considered water systems was created based on material from the historical GIS for the spatial history of the Russian Empire by Kelly O'Neill's “Canvas Empire" [36], on Kashina et al. [37], Shirokova et al. [38,39], and Otsenka kachestva vody [40].

\subsection{Supplemental Data}

Species Status of the Animals and Morphology

Most of the external characters used in lamprey taxonomy are limited to adult specimens. However, the Key to Lamprey Adults of the World [7] allows distinguishing representatives of the genera potentially inhabiting the discussed area. To estimate the position of the specimens from the samples of adult lamprey, we performed a supplemental study of key and diagnostic features (Supplementary 1). The analysis was based mainly on comparison of samples from the studied area to samples from the Baltic Sea Basin (Russian part) and additionally including samples from the Iberian Peninsula [41], with descriptions given in [7] for Caspiomyzon wagneri, Lethenteron camtschaticum, and Eudontomyzon mariae. A total of 25 samples of lamprey related to the genus Lampetra (over 500 specimens) were analyzed.

The detailed characteristics of the adults from Vysochinsky Stream, Saragozha River, and Bolshaya Sestra River were based on 17 measurements, besides the attention that was paid to coloration and pigmentation.

Genetics. On the first step of the genetic analysis (Supplementary 2) the obtained Cyt-b haplotype from the Upper Volga (Table S1 in Supplementary 2) was compared with known haplotypes of various European Lampetra (Table S2 in Supplementary 2), Caspiomyzon wagneri (GenBank: GQ206152.1), Lethenteron camtschaticum (GenBank: KX691482.1), and Eudontomyzon mariae (GenBank: AM051061.1). The position of the detected haplotype in 
the Upper Volga relative to the most common and widely distributed (ancestral) haplotype was also established based on data published in the NCBI. To estimate possible kinship of the lampreys from Baltic and Upper Volga watersheds, we additionally sequenced nine specimens from six localities in the Baltic Sea Basin (Russian part). After that, the analysis of these two haplotypes' distribution was performed.

\section{Results}

\section{Reconfirmation of the Lamprey Taxonomy}

External attributes and dentition of the lamprey allowed us to confirm that the adult specimens (Figure S1a in Supplementary 1) and larvae (Table S2 in Supplementary 2) collected were European river lamprey, Lampetra fluviatilis. In adults, the cloaca was posterior to the origin of the second dorsal fin, under its first half. Oral papillae were very small and of uniform size along the entire perimeter of the oral disc. Eyes were dorsolateral and teeth were blunt in most specimens (Figure 3). Exolateral rows were without dentition. Three rows of right and three rows of left endolaterals were present. The second rows of endolaterals always had three cusps. Supraoral lamina with two unicuspid teeth was separated by a bridge without dentition. Marginal cusps of the infraoral lamina were larger than the inner ones, usually bicuspid (sometimes asymmetric). In total, 6-10 cusps were counted on the infraoral lamina. Anterial rows bore 0-2 teeth; if teeth were present, 0-7 anterial teeth in the first row. Posterior teeth were absent. Trunk myomeres were 58-77 in number. Relative size (\% of the body length) in specimens with total length 123-151 mm: prebranchial length,5.5-13.9; branchial length, 8.3-15; trunk length, 44.4-59.8; tail length, 24.2-31.4; and disc length, 4-6.Detailed body proportions for adult lampreys from the Kamenka were not investigated because specimens were preserved with alcohol. Characterics of males and females from Vysochinsky Stream, Saragozha River, and Bolshaya Sestra River are provided in Table 2.

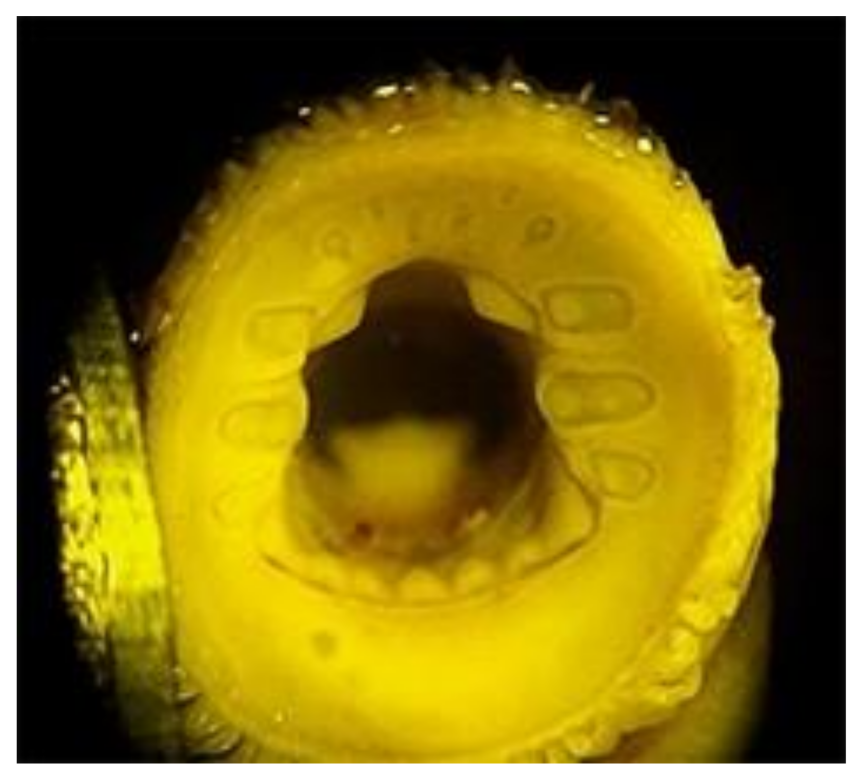

Figure 3. Oral disc of the European river lamprey Lampetra fluviatilis (Kamenka River). 
Table 2. Morphometrics in Lampetra fluviatilis mature adults. Data above the line are the ranges, and under the line is the mean $\pm \mathrm{SE}$.

\begin{tabular}{|c|c|c|c|c|c|c|}
\hline \multirow[t]{2}{*}{ Characters } & \multicolumn{2}{|c|}{ Vysochinsky } & \multicolumn{2}{|c|}{ Saragozha } & \multicolumn{2}{|c|}{ Bolshaya Sestra } \\
\hline & Males $(n=14)$ & Females $(n=16)$ & Males $(n=3)$ & Females $(n=4)$ & Males $(n=9)$ & Females $(n=5)$ \\
\hline \multirow[t]{2}{*}{$T L, \mathrm{MM}$} & 127-151 & 123-150 & 134-142 & 126-133 & 125-151 & 117-132 \\
\hline & $138.5 \pm 1.75$ & $135.0 \pm 1.75$ & $\begin{array}{c}137.3 \pm 2.85 \\
\% T L\end{array}$ & $129.8 \pm 1.65$ & $138.2 \pm 2.99$ & $127.2 \pm 2.75$ \\
\hline \multirow[t]{2}{*}{$H$} & $4.9-7.4$ & $3.7-8.0$ & 6.3-7.4 & $5.6-8.0$ & $4.6-7.2$ & $5.3-6.1$ \\
\hline & $6.0 \pm 0.15$ & $5.6 \pm 0.21$ & $6.7 \pm 0.36$ & $6.8 \pm 0.53$ & $6.1 \pm 0.24$ & $5.7 \pm 0.15$ \\
\hline \multirow[t]{2}{*}{$a B 1$} & $10.8-13.3$ & 8.6-13.9 & $12.2-13.3$ & $12.0-13.9$ & $9.6-12.1$ & $5.5-11.4$ \\
\hline & $12.2 \pm 0.17$ & $11.6 \pm 0.29$ & $12.8 \pm 0.32$ & $12.8 \pm 0.40$ & $10.8 \pm 0.24$ & $9.6 \pm 0.90$ \\
\hline \multirow[t]{2}{*}{$B 1-B 7$} & $9.0-11.6$ & $10.1-15.0$ & $9.7-10.7$ & $10.5-11.9$ & 8.3-10.1 & $5.5-10.3$ \\
\hline & $10.4 \pm 0.20$ & $11.4 \pm 0.25$ & $10.2 \pm 0.30$ & $11.2 \pm 0.36$ & $9.5 \pm 0.25$ & $8.8 \pm 0.90$ \\
\hline \multirow[t]{2}{*}{$a B 7$} & $18.7-23.0$ & $18.4-23.4$ & $21.6-33.0$ & $21.1-23.4$ & $17.2-20.3$ & $18.2-21.2$ \\
\hline & $20.4 \pm 0.30$ & $20.6 \pm 0.28$ & $22.3 \pm 0.38$ & $22.4 \pm 0.50$ & $18.8 \pm 0.35$ & $20.0 \pm 0.54$ \\
\hline \multirow[t]{2}{*}{$o-B 1$} & $3.4-4.8$ & $3.2-5.3$ & $3.7-4.5$ & $4.0-4.5$ & $2.8-4.0$ & 2.6-3.9 \\
\hline & $4.2 \pm 0.09$ & $4.1 \pm 0.13$ & $4.1 \pm 0.23$ & $4.3 \pm 0.13$ & $3.3 \pm 0.13$ & $3.4 \pm 0.25$ \\
\hline \multirow[t]{2}{*}{$o$} & $2.1-3.9$ & $2.2-4.0$ & $3.5-3.7$ & $3.4-3.9$ & $2.1-3.2$ & $1.6-3.0$ \\
\hline & $3.2 \pm 0.13$ & $3.1 \pm 0.13$ & $3.6 \pm 0.07$ & $3.7 \pm 0.13$ & $2.7 \pm 0.10$ & $2.3 \pm 0.23$ \\
\hline \multirow[t]{2}{*}{$d$} & $4.7-6.7$ & $4.5-6.1$ & $5.6-6.7$ & $5.3-6.0$ & $4.4-5.7$ & $3.1-4.7$ \\
\hline & $5.7 \pm 0.10$ & $5.2 \pm 0.09$ & $6.1 \pm 0.31$ & $5.6 \pm 0.17$ & $5.2 \pm 0.16$ & $4.3 \pm 0.30$ \\
\hline \multirow[t]{2}{*}{ io } & $4.5-6.7$ & $4.0-7.9$ & $5.6-6.7$ & $6.0-7.9$ & $3.3-5.0$ & $3.8-5.1$ \\
\hline & $5.4 \pm 0.13$ & $5.2 \pm 0.22$ & $6.2 \pm 0.32$ & $6.8 \pm 0.43$ & $4.4 \pm 0.20$ & $4.5 \pm 0.22$ \\
\hline \multirow[t]{2}{*}{ lD1 } & $13.8-17.7$ & 12.9-17.8 & $13.8-15.0$ & $12.9-16.7$ & 4.9-17.0 & $13.3-18.8$ \\
\hline & $15.8 \pm 0.28$ & $15.9 \pm 0.30$ & $14.6 \pm 0.38$ & $15.3 \pm 0.85$ & $15.9 \pm 0.24$ & $16.0 \pm 0.88$ \\
\hline \multirow[t]{2}{*}{ lD2 } & $25.4-31.1$ & 25.4-30.7 & 26.9-29.3 & $26.6-28.8$ & $25.4-27.7$ & $22.7-28.2$ \\
\hline & $27.5 \pm 0.37$ & $27.6 \pm 0.35$ & $27.9 \pm 0.69$ & $27.7 \pm 0.48$ & $26.7 \pm 0.27$ & $25.1 \pm 0.90$ \\
\hline \multirow[t]{2}{*}{$h D 1$} & $2.3-4.2$ & $1.4-4.4$ & $3.7-4.2$ & 2.3-3.5 & $2.3-4.0$ & $1.9-2.7$ \\
\hline & $3.3 \pm 0.17$ & $2.6 \pm 0.17$ & $3.9 \pm 0.16$ & $3.0 \pm 0.27$ & $3.4 \pm 0.19$ & $2.3 \pm 0.14$ \\
\hline \multirow[t]{2}{*}{$h D 2$} & $3.7-6.7$ & $3.3-6.1$ & $4.9-6.7$ & $4.1-5.6$ & $3.4-6.4$ & $3.9-5.5$ \\
\hline & $5.4 \pm 0.21$ & $4.8 \pm 0.16$ & $5.6 \pm 0.54$ & $5.0 \pm 0.37$ & $5.5 \pm 0.29$ & $4.8 \pm 0.26$ \\
\hline \multirow[t]{2}{*}{$a-C$} & $25.3-31.4$ & $25.2-30.0$ & $28.0-29.6$ & $25.8-27.0$ & $27.8-31.5$ & $24.2-27.4$ \\
\hline & $29.0 \pm 0.36$ & $27.0 \pm 0.29$ & $28.7 \pm 0.50$ & $26.6 \pm 0.29$ & $29.8 \pm 0.44$ & $25.2 \pm 0.57$ \\
\hline \multirow[t]{2}{*}{$l C$} & $7.0-12.4$ & 9.0-14.6 & $10.0-10.8$ & $10.2-11.9$ & $9.3-13.5$ & $9.4-11.8$ \\
\hline & $10.3 \pm 0.27$ & $10.5 \pm 0.29$ & $10.4 \pm 0.24$ & $10.8 \pm 0.41$ & $11.5 \pm 0.41$ & $10.2 \pm 0.42$ \\
\hline \multirow[t]{2}{*}{$B 7-a$} & $45.9-53.1$ & $48.9-56.4$ & $45.9-48.5$ & $48.9-52.4$ & $44.4-49.3$ & $43.2-59.8$ \\
\hline & $49.4 \pm 0.41$ & $52.6 \pm 0.39$ & $47.7 \pm 0.82$ & $50.9 \pm 0.75$ & $47.6 \pm 0.49$ & $51.8 \pm 2.67$ \\
\hline \multirow[t]{2}{*}{$a n$} & $6.2-8.5$ & $5.8-8.2$ & 7.3-7.8 & $6.4-8.2$ & $4.5-7.5$ & $5.3-6.8$ \\
\hline & $7.0 \pm 0.14$ & $6.8 \pm 0.13$ & $7.5 \pm 0.13$ & $7.3 \pm 0.38$ & $6.9 \pm 0.30$ & $6.0 \pm 0.27$ \\
\hline
\end{tabular}

Note: Variables: $T L$, total length; $H$, body depth; $a$-B1, prebranchial length; $B 1-B 7$, branchial length; $a B 7$, head length; $a o$, preocular length; $o B 1$, postocular length; $o$, eye diameter; $d$, disc length; $i o$, interocular distance; $l D 1$, first dorsal length; $l D 2$, second dorsal length; $h D 1$, first dorsal depth; $h D 2$, second dorsal depth; $a-C$, tail length; $l C$, caudal length; $B 7-a$, trunk length; $a$, prenostril length

Coloration of the lampreys from the Vysochinsky Stream was dark dorsally and silvery on the lateral sides, which is characteristic of juvenile European river lamprey during downstream migration (Figure 4A). The coloration of males and females from the Kamenka River and males from the Saragozha River was dark brown dorsally and light on the ventral side (Figure 4B,C). Females from the Saragozha River were olive or light brown on the dorsal side and olive or sandy on the lateral sides. The dorsal part of the branchial area was colored, the ventral part light, and the oral disc was not pigmented. Despite the coloration of specimens from the Vysochinsky Stream, all the lampreys had well-expressed secondary sexual characteristics and developed reproductive features. 


\section{A}

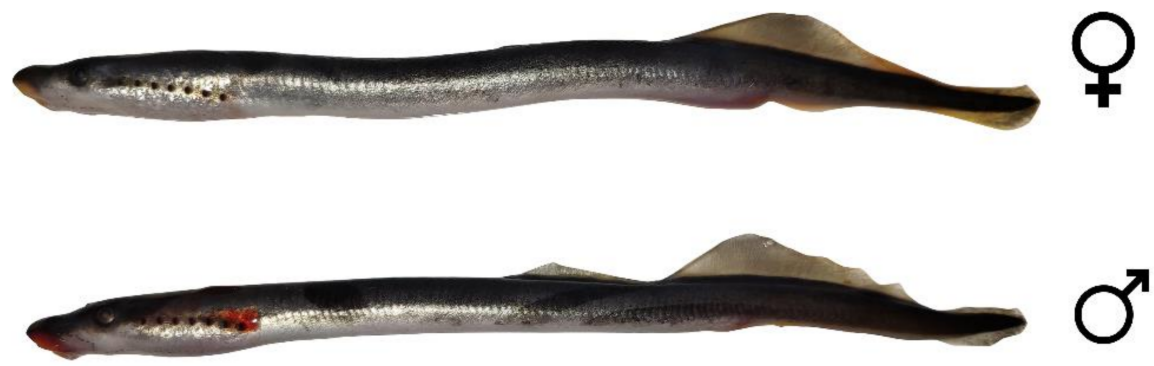

B
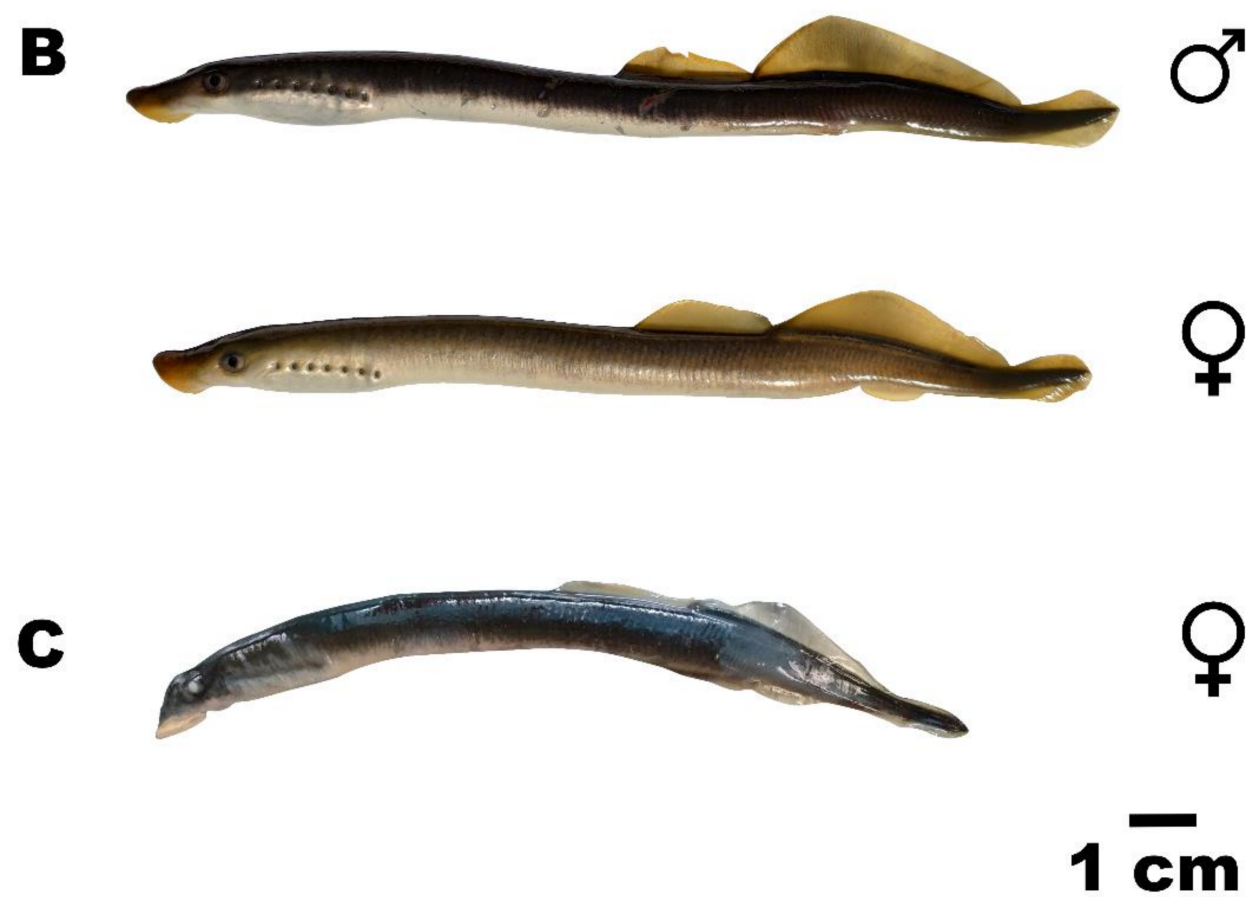

Figure 4. External appearance of mature adults of the European river lamprey, Lampetra fluviatilis, collected from the Vysochinsky Stream (A), Saragozha (B), and Kamenka (C) rivers in the spawning period.

Supplemental data (Figure S1b in Supplementary 1) showed that the diversity of the adult lampreys from the studied area were closely related to that from the Baltic Sea Basin. The greatest similarity to the adult lampreys from Saragozha, Vysochinsky, Kamenka, and Bolshaya Sestra was showed by the resident adult specimens from Serebristaya, Chernaya, Plyussa, and Izhora.

Genetic analysis of the Cyt-b gene fragment confirmed (Supplementary 2) that the analyzed specimens from the Yakhroma and Bolshaya Sestra rivers belong to representatives of the Lampetra fluviatilis-planeri complex, and their haplotype is one of the most widely distributed in this species. Furthermore, their haplotype was equal to the haplotype (2 specimens), designated as Lampetra planeri, found before in the Linda River, which is a tributary of the Volga River as well (Table S2 in Supplementary 2).

Proceeding from the commonality of the studied lampreys of the Caspian and Baltic basins and the assumption that the populations in the Volga Basin originated from populations from the Baltic, based on analysis of satellite imagery and information in the literature [37-39], we calculated the distances between sites where lamprey were sampled and the Volga-Baltic watershed boundary (Table 3). 
Table 3. Extrapolated distances of dispersal of the European river lamprey Lampetra fluviatilis along the rivers of the Upper Volga Basin.

\begin{tabular}{|c|c|c|c|}
\hline Site & Water Course & $\begin{array}{c}\text { Coordinates of the Capture } \\
\text { Site }\end{array}$ & $\begin{array}{c}\text { Distance }(\mathbf{k m}) \text { from the Water-Parting Line, } \\
\text { Downstream } \\
\text { Upstream }\end{array}$ \\
\hline 1 & Vysochinsky Stream & $58^{\circ} 17^{\prime} 06.00^{\prime \prime} \mathrm{N}, 35^{\circ} 31^{\prime} 22.74^{\prime \prime} \mathrm{E}$ & $\begin{array}{c}226 \\
185.8\end{array}$ \\
\hline 2 & Saragozha River & $58^{\circ} 16^{\prime} 24.14^{\prime \prime} \mathrm{N}, 35^{\circ} 36^{\prime} 03.11^{\prime \prime} \mathrm{E}$ & $\begin{array}{l}226 \\
151\end{array}$ \\
\hline 3 & Volchina River & $57^{\circ} 45^{\prime} 39.46^{\prime \prime} \mathrm{N}, 35^{\circ} 46^{\prime} 19.31^{\prime \prime} \mathrm{E}$ & $\begin{array}{l}226 \\
236\end{array}$ \\
\hline 4 & Kamenka River & $58^{\circ} 11^{\prime} 56.24^{\prime \prime} \mathrm{N}, 37^{\circ} 51^{\prime} 24.83^{\prime \prime} \mathrm{E}$ & $\begin{array}{c}369 \\
15\end{array}$ \\
\hline 5 & Tunoshonka River & $57^{\circ} 32^{\prime} 31.82^{\prime \prime} \mathrm{N}, 40^{\circ} 06^{\prime} 57.54^{\prime \prime} \mathrm{E}$ & $\begin{array}{l}612 \\
1.3\end{array}$ \\
\hline 6 & Malaya Dubenka River & $56^{\circ} 51^{\prime} 13.66^{\prime \prime} \mathrm{N}, 33^{\circ} 14^{\prime} 42.71^{\prime \prime} \mathrm{E}$ & $\begin{array}{l}188 \\
348\end{array}$ \\
\hline 10 & Kava River & $57^{\circ} 08^{\prime} 09.54^{\prime \prime} \mathrm{N}, 35^{\circ} 32^{\prime} 01.63^{\prime \prime} \mathrm{E}$ & $\begin{array}{c}169.8 \\
46.7\end{array}$ \\
\hline 11 & Vyazma River & $56^{\circ} 28^{\prime} 46.63^{\prime \prime} \mathrm{N}, 35^{\circ} 49^{\prime} 17.18^{\prime \prime} \mathrm{E}$ & $\begin{array}{c}245 \\
62\end{array}$ \\
\hline 12 & Bolshaya Sestra River & $56^{\circ} 03^{\prime} 57.04^{\prime \prime} \mathrm{N}, 36^{\circ} 14^{\prime} 25.10^{\prime \prime} \mathrm{E}$ & $\begin{array}{c}245 \\
125.5\end{array}$ \\
\hline 14 & Yakhroma & $56^{\circ} 25^{\prime} 16.62^{\prime \prime} \mathrm{N}, 37^{\circ} 23^{\prime} 25.50^{\prime \prime} \mathrm{E}$ & $\begin{array}{l}310 \\
70.6\end{array}$ \\
\hline
\end{tabular}

Note: Distances were calculated for the Tikhvin water system (1-5) and the Vyshnii Volochek water system (6, 10-12). Site numbers as in Figure 1 .

\section{Discussion}

Based on the analysis of key features [4], all studied samples fell into the Lampetra clade (Figure S1a in Supplementary 1). The samples from the Upper Volga are closely related (Figure S1b in Supplementary 1) to the samples of resident European river lamprey from the Baltic Basin, which is clearly seen when comparing with the Portuguese samples (Figure S1c in Supplementary 1; keys for European Lampetra do not include geographic criteria). These samples grouped with samples from the Serebristaya, Chernaya, Plyussa, and Izhora rivers. Lampreys in all these locations have trunk myomeres, usually 53-65 (but maximal 77 in Kamenka, Bolshaya Sestra, and Serebristaya); disc length/total length, about $6.0 \%$ (4.6-7.0\%), and eye length/total length, usually about $2.3-2.6 \%$. Adults from the Upper Volga differ from those from Baltic rivers with their dentition, as they usually have 2 rows of anterials with up to $3-5$ teeth in the first row (which is usual for anadromous and lake forms in Baltic, as well as for resident Portuguese lampreys).

The coloration of adults from the surveyed populations was diverse. Lampreys from the Saragozha and Kamenka rivers were, in general, colored similarly to adults of European river lamprey from various rivers of Europe $[3,7,42]$. The coloration of adults from the Vysochinsky Stream merits a special discussion. Their silvery coloration is characteristic of post-metamorphic juveniles (transformers, macrophtalmia) during downstream migration [43-45]. Sperone et al. [46] found what is deemed the southernmost resident population of the European river lamprey (they call it the European brook lamprey L. planeri) in the Lao River (Calabria, Italy). They documented two such specimens on 26 October 2018, in an electrofishing survey (total length 170 and $175 \mathrm{~mm}$ ). It is clear from a photograph of this specimen with silvery coloration (p. 133, and the figure in [46]) that it is not an adult but a post-metamorphic immature specimen (secondary sexual characteristics are absent). Most likely, it was a European river lamprey smolt. Among the other resident species of Lampetra, a silvery coloration was also noted for Lampetra aepyptera [7]. It is unclear if the silvery coloration of the lampreys is associated with their migratory activity and why lampreys from the Vysochinsky Stream do not lose this coloration upon maturation. 
These questions might open avenues for further research and reinforce the need for genetic analysis of archived specimens.

According to Renaud [7], the resident form of the European river lamprey (L. planeri sensu Renaud 2011) has a maximum total length of $170 \mathrm{~mm}$. Kucheryavyi et al. [47] grouped specimens from Serebristaya according to length categories: "dwarf" (78-83 mm), "small" (90-104 mm), and "common" (107-140 mm). Following these categories, lamprey from the Kamenka River were classified as "small" $(n=1)$ and "common" $(n=4)$. All adults from the Saragozha River were "common" $(n=7)$. In the Vysochinsky Stream, 63\% $(n=19)$ of the lampreys were "common", while $37 \%(n=11)$ were attributed to a new category, "large", which includes individuals over $141 \mathrm{~mm}$. The same for Bolshaya Sestra River, where "common" specimens appear together with "large" ones, $29 \%$ ( $n=4$, all males). Lampreys like these have been recorded in northwestern Scotland (in the Endrick River, a tributary of the Loch Lomond-[48]) and in isolated populations in Spain (the Deva-Cares system) and Portugal (Esmoris and Vouga Rivers) [41,49].

One of the hypotheses explaining the presence of landlocked lamprey (e.g., resident European river lamprey in the Upper Volga or lake form sea lamprey Petromyzon marinus in the Lake Ontario) considers the impact of global climate change on the ichthyofauna 70-10 thousand years ago. Lawrie [50] and Smith [51] believe that the sea lamprey inhabiting the lake and its drainages is a relict Pleistocene population from North America. Dorofeev et al. [52] and Slynko and Tereshchenko [30] suggest that the retreat of the Valdai glaciation in Europe under the influence of global warming (12-10 thousand years ago) resulted in the formation of numerous periglacial lakes and other water bodies of glacial origin. Owing to this, the entire Ponto-Caspian Basin was populated by fish species of the Arctic freshwater and boreal-submontane faunal complexes. The European river lamprey belongs to the latter group. This is how Slynko and Tereshchenko [30] explain the presence of the European river lamprey in the tributaries of the Upper Volga, the Ivankovo, the Uglich, and the Rybinsk Reservoir.

If the European river lamprey had inhabited the Upper Volga for more than 11,000 years, its local populations would have mixed, resulting in homogeneous phenotypes. Lamprey from the Vysochinsky Stream, the Saragozha River, and the Kamenka River, however, exhibit diverse phenotypes (Figure 4). These water courses are located close to each other, un-separated by physical barriers, and have similar hydrological characteristics (all of them are lowland rivers), all of which suggests a more recent invasion of European river lamprey into this region.

In this paper, among all the known diversity of haplotypes, we discuss only two: the most common in the range (ancestor haplotype) and one identified as a descendant haplotype, which was found, i.a., in the Upper Volga. The descendant haplotype is widely distributed in the range down to its southern boundary (Figure S1 in Supplementary 2). Another feature of this haplotype is that it was found in both resident and migrant lampreys.

It is notable that within the Baltic Basin in the Ilmen Lake was found the ancestor haplotype, and in the Syas River both haplotypes. The Ilmen Lake is a part of the Vyshnii Volochek Hydrological System, and the Syas River belongs to the Tikhvin one. In addition, the descendent haplotype was found in other watercourses of the Upper Volga, and also spread further down to the Azov-Black Sea Basin where the catch of an anadromous European river lamprey was documented (Figure S1 in Supplementary 2).

Therefore, we present the invasion hypothesis, which suggests colonization of the European river lamprey into the system of the Volga River via manmade shipways. Extremely low numbers of the European river lamprey in the entire Upper Volga are likely a consequence of the construction of dams for hydroelectric energy production, which caused limnification of the river and a decrease in the abundance of rheophilic species, including lamprey.

In the early 18th century, the Caspian, Baltic, and White Sea basins were not yet connected (Figure 5). Shipways connecting the Upper Volga with the Baltic Basin started with construction of the Vyshnii Volochek water system (groundwork completed in 1708). 
Essentially, the basins of these different seas were connected following this construction. Officially, the water systems in question were opened some years later (max. 6 years later), due to the need to build sluices for ship passage. This was followed by the Tikhvin water system (1805) and by the Mariinskaya water system (1808), which is now called the Volga-Baltic water system [37-39]. The North Dvina water system connected the Caspian and the White Sea basins in 1828 [40]. The development of the system of shipways opened new water courses, along which various aquatic organisms, including fish and cyclostomes, have been dispersing for more than 300 years. Dispersal along the Volga was unimpeded until the construction of the first dam, the Upper Volga Beishlot (1843), which separated the lakes of the Upper Volga from the rest of the river. The dispersal pathways along the Upper Volga were blocked altogether after the construction of hydroelectric stations near Ivankovo (Dubna) (1937), Uglich (1940), Rybinsk (1941), and Nizhny Novgorod (1955).

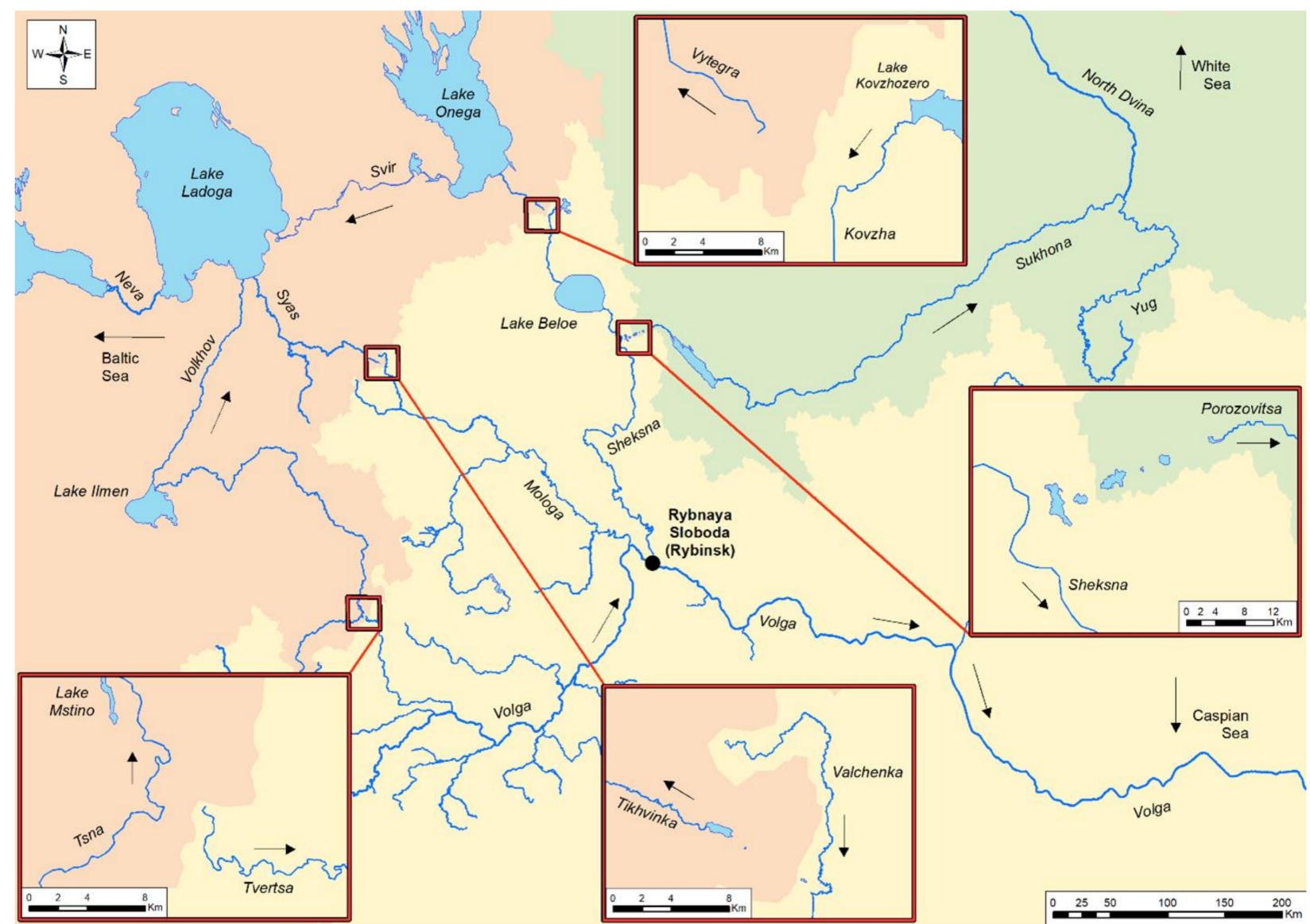

Figure 5. Water systems of the Baltic $(\square)$, the Caspian $(\quad$ ), and the White $(\square)$ seas prior to the construction of the artificial shipways system (1703) and dams (1843).

The Volga River system is now one of the major invasion corridors of Europe. According to Konovalov et al. [53], aquatic organisms mainly disperse from the Caspian Basin northwards to the Baltic Basin (i.e., the Volga pikeperch Sander volgensis, blue bream Ballerus ballerus, and wels catfish Silurus glanis) and the White Sea Basin (i.e., sterlet Acipencer ruthenus and spined loach Cobitis taenia). This, probably, was made possible not only by the shipways but also because global warming causing northward displacement of a number of the species [54]. Dispersal in the opposite direction has been noted for fewer fish species, mainly due to a small adult size and short life cycle [55]. It may also be associated with the regulation of the run-off of the Volga River, which results in an increase in the water temperature, low oxygen conditions, a change in the water mineralization, demands on spawning substrate, and increasing eutrophication [28]. 
Several instances of southward dispersal have been discussed in the literature. Large numbers of the juveniles of the European eel, Anguilla anguilla, were released into Lake Seliger in 1960-1967, and this species soon became widespread in the entire Volga River [28]. Its regular presence in catches decades after the artificial stocking indicates that the eels migrate on their own from the Baltic Sea into the Upper Volga along the shipways of the Volga-Baltic system [56]. According to Konovalov et al. [53], the young European eels reach Lake Beloe $(\sim 645 \mathrm{~km})$, the Sheksna Reservoir $(\sim 690 \mathrm{~km})$, and, in rare instances, the Rybinsk Reservoir $(861 \mathrm{~km}$ ), including the Mologa River Basin (distances are given from the Baltic Sea). According to Yakovlev et al. [57], the nine-spined stickleback Pungitius pungitius from Lake Onega reached the Vytegra Reservoir $(\sim 15 \mathrm{~km})$ and the basin of Lake Beloe $(\sim 132 \mathrm{~km})$.

After the Volga became connected with the White Sea Basin through the North Dvina water system in 1828 [40], the invasion of representatives of the order Petromyzontiformes inhabiting these seas-the European river lamprey and the Arctic lamprey Lethenteron camtschaticum - would have been expected. The Arctic lamprey has not been documented in the Caspian or Baltic Basin, at least in our study area. Its range is restricted to the Sukhona River, which stems from the Kubenskoe controlled-flow reservoir (a former relict lake) with a dam Znamenitaya (1834). Construction of the Mariinskaya Hydrological system transformed the system of lakes and the Porozovitsa River into a channel, and the Znamenitaya dam provided access from the Baltic Basin to the White Sea Basin. Some species have taken advantage of this. Lebedev [58] reported that the European smelt Osmerus eperlanus has resettled from Lake Beloe (Baltic Basin) to Kubenskoe Reservoir (White Sea Basin). Similarly, the European river lamprey has used this route and now occurs in the Sukhona River [59].

The European river lamprey could have invaded the Upper Volga Basin along either of the three water systems Vyshnii Volochek, Tikhvin, and Mariinskaya over the past 312, 215 , and 212 years, respectively. The Tikhvin water system is the shortest of the three, being $922 \mathrm{~km}$ long from the Neva mouth to Rybinsk. The Vyshnii Volochek and the Mariinskaya are longer, 518 and $221 \mathrm{~km}$, respectively [39]. The distances that the European river lamprey could cover in the process of invasion along the Tikhvin water system from the mouth of the Neva to the studied water courses are $833.3 \mathrm{~km}$ to the mouth of the Vysochinsky Stream, $905.6 \mathrm{~km}$ to the mouth of the Volchina River, $839.5 \mathrm{~km}$ to the mouth of the Kamenka River along the water courses that had existed before the construction of the Rybinsk Reservoir (Figure 5), and $1069.3 \mathrm{~km}$ to the mouth of the Tunoshonka River.

The Tikhvin water system is closer than the other two to the system of the Saragozha River and to the Volchina River and Kamenka River. The Vyshnii Volochek water system is situated in direct proximity to the Vyazma River, the Bolshaya Sestra River, Yakhroma River, the Malaya Dubenka River, the Malaya and the Bolshaya Kosha rivers, the Shutinka Stream, the Kava River, and a collection sites of European river lamprey found in studies by Viktorov [26], Viktorov et al. [27], and Nezdolii and Kirillov [22]. We consider these two systems of shipways as the most probable invasion pathways of the European river lamprey from the Baltic to the Caspian Basin in the corresponding parts of the distribution. However, distance cannot be the only criterion in this matter. To ascertain the pathways used by the European river lamprey for the invasion in the Caspian Basin, phenogeographic studies are necessary.

The abovementioned reasoning - that the colonization pathways opened due to human activity-closely resembles the process underway in the North American Laurentian Great Lakes. While the situation with Lake Ontario remains a topic of debate, the remaining invasion pathways are clear to most researchers. Sea lamprey (Petromyzon marinus) has spread throughout the system of lakes due to the construction of channels, which made it possible to bypass Niagara Falls. It took only 25 years for sea lamprey to get to the farthest point, Lake Superior [60]. Relevant is that as both sea and European river lamprey penetrate more deeply into these freshwater systems, their size as adults and fecundity decreases, producing parasitic lake forms. The European river lamprey goes further to 
evolve a nonparasitic resident form [3], which after metamorphosis has no need to feed and can disperse widely and inhabit more types of habitats.

Anadromous lampreys are quite capable of covering the distances mentioned above over the course of one upstream migration [3]. For instance, the presence of an anadromous lamprey from the Gdovka River, in the collection of the Museum of the Zoological Institute of the Russian Academy of Sciences (ZISP 25430-25433), indicates that the European river lamprey could migrate up the Narva River and cross Lake Peipus, covering more than $3000 \mathrm{~km}$ in total. In water-abundant years, lampreys in the Luga River overcame the Kingisepp and Sabsk rapids and entered the tributaries of the Luga, e.g., the Krupa River, ascending $150 \mathrm{~km}$ upstream (ZISP 26437; 26438).

A possible scenario for the dispersal of European river lamprey into the Upper Volga, based on the evidence from the Tikhvin water system, is as follows. Anadromous lamprey adults were observed in the Syas River [61]. Berg (ZISP 39080; 42976) and Ivanova-Berg (ZISP 42977) ascertained the presence of adults of the lake form in that river. This means that anadromous lampreys could have migrated upstream from the Baltic Sea along the Syas River up to the upper reaches of the Tikhvinka River, i.e., up to the watershed boundary $(457.3 \mathrm{~km})$. For the lake form of lampreys from Lake Ladoga, this pathway is $271.3 \mathrm{~km}$ long.

Groundwork on the Tikhvin water system was completed in 1805 [39], establishing the connection between the Baltic and the Caspian basins. After that, anadromous, lake adults (or resident adults from the Syas and the Tikhvinka) could cross the watershed boundary and start migrating along the Volga slope. Further downstream dispersal along the rivers of the Tikhvin water system and the Volga River was achieved by larval stages. Primary dispersal in the form of downstream migration is documented for lamprey aged $0+[62,63]$, while downstream migration of older ammocoetes has been repeatedly recorded in various rivers throughout the year. During downstream migrations, lampreys can cover considerable distances (tens of kilometers) over a short period of time. This means that it could take as little as several decades for the species to disperse across the Upper Volga. Upstream dispersal into rivers such as the Saragozha, Volchina, Kamenka, and Tunoshonka could be achieved both by the resident adults and by the larvae of the European river lamprey [64].

Thus, the mechanism employed by the European river lamprey for colonization of the Caspian Basin was likely a combination of upstream and downstream migrations. At the first stage, the lampreys migrated upstream along the rivers of the Baltic Basin until they reached the watershed boundary. Reaching and crossing this boundary became possible owing to anthropogenic interference: the construction of sluices on the rivers (allowing lampreys to navigate up the rapids) and on the watershed boundary, and the opening of shipways. The second stage was represented by mass, mostly downstream migrations along the rivers of the Caspian Basin. Dispersal along the Volga River system was also a combination of upstream and downstream migrations in accordance with the migration cycle of the European river lamprey.

The European river lamprey-a species capable of long-term and long-distance migrations both upstream and downstream-could disperse across the Caspian Basin along corridors of anthropogenic origin. The considerable morphological diversity of its local populations reported in our study provides evidence for this hypothesis. The diversity of lamprey from the Vysochinsky Stream, Saragozha River, Bolshaya Sestra River, and Kamenka River is probably associated with the fact these young (not more than 60 generations) local populations formed from a small number of pioneering adults.

\section{Conclusions}

Invasion is a constant process associated with changes in the environment for a long time. With the development of anthropogenic influence, a new type of territory capture appeared, which is related to human activity. For species that have aroused human interest over the course of the past 200-300 years, it is relatively easy to establish the date when a particular territory was invaded. Small forms of lampreys started to arouse the interest of 
researchers only at the end of the 19th century, and since they have no commercial value, there is practically no information on them in earlier historical documents.

Previously, it was believed that the European lamprey populated the Upper Volga basin as a result of the retreat of the Valdai glaciation. Our studies showed another possible way, via hydrological systems. Resident lampreys in the Upper Volga are similar to resident specimens from the Baltic. Among their mature specimens, the same size groups ("dwarf", "small", and "common") are found, and their key features (number of trunk myomeres, dentition, and disc and eye diameters) are comparable to those of specimens from the rivers of the Baltic basin. At the same time, in the populations of the Upper Volga, there are signs of the "influence" of anadromous lampreys; for example, two rows of anterials, a silvery body coloration, and a "large" size group.

Tracking the distribution of one of the most common haplotypes in the European river lamprey made it possible to suggest routes of invasion. Although a study like this requires big data, with what we had, we already can confirm, with a high probability, the recent invasion from the system of rivers and lakes of the Baltic Basin by hydrological systems.

In this work, we briefly traced more than three hundred years of human influence on populations of lampreys of different genera, each of which is unique in its biology and ability to adapt to new conditions. Changing landscapes, i.e., the construction of navigable canals, united different sea basins in the interior of the mainland, which led to the discovery of new potential habitats in fresh waters unfamiliar for these species. Most likely, this led to increased competition. The construction of hydraulic structures on the largest river in Europe led to the blocking of the migration routes of the anadromous species, with species such as the Caspian lamprey having lost in the competitive struggle, since it is not able to form freshwater populations. Representatives of the genus Lethenteron are currently not known in the Volga, which is most likely also associated with the development of dams. Lampreys from the genera Lampetra and Eudontomyzon, which today "share" the territory upstream the hydropower stations, remained "the winners in this race for territory". In turn, the range-reduced Caspiomyzon remains in the lower part of the river.

Supplementary Materials: The following are available online at https:/ / www.mdpi.com/article/10 $.3390 / w 13131825$ /s1, Table S1: Results of analysis of the Euclidian distances for each pair of samples. Figure S1: Analyses of lampreys diversity based on their key features. Table S2: Cyt-b (1173 bp) of the lamprey from Bolshaya Sestra and Yakhroma rivers. Table S3: Results for the Cyt-b haplotype of the lamprey from Bolshaya Sestra (12) and Yakhroma (14) rivers comparation to the deposited in the open sources data. Figure S2: Known distribution of the ancestor and descendant haplotypes on the range of the Lampeta fluviatilis-planeri complex and their possible migration paths.

Author Contributions: A.O.Z.: Field works, maps analysis, historical data analysis, MS; A.V.K. (Aleksandr V. Kucheryavyy): specimens' morphology, description, figures, MS; A.V.K. (Anzhelika V. Kolotei): maps analysis, distances, figures, MS; N.V.P.: statistics, MS; D.S.P.: MS. All authors have read and agreed to the published version of the manuscript.

Funding: The work was carried out with the financial support of the Russian Science Foundation, Project No 19-14-00015.

Institutional Review Board Statement: All animal experiments were performed in accordance with guidelines approved by Institute of Ecology and Evolution (Moscow, Russia) Animal Committee and handled in accordance with the 1986 Animals (Scientific Procedures) Act and Helsinki Declaration.

Informed Consent Statement: Not applicable.

Data Availability Statement: Samples designated IEE are stored in collection of lampreys in Institute of Ecology and Evolution, Russian Academy of Sciences, Moscow, Russia. Samples designated ZISP are stored in the fish collection of the Zoological Institute, Russian Academy of Sciences, Saint Petersburg, Russia. Distances measured based on satellite images of public sources Google Earth and Google Maps. 
Acknowledgments: We are grateful to Mary Moser (National Oceanic and Atmospheric Administration, USA), Yuriy Reshetnikov (A.N. Severtsov Institute of Ecology and Evolution, Russia) for useful advice and valuable comments, and Audrey Thompson for the text editing.

Conflicts of Interest: Authors declare no conflict of interest.

\section{References}

1. Artamonova, V.S.; Kucheryavyy, A.V.; Makhrov, A.A. Nucleotide sequence diversity of the mitochondrial cytochrome oxidase subunit I (COI) gene of the Arctic lamprey (Lethenteron camtschaticum) in the Eurasian part of the range. Hydrobiologia 2016, 757, 197-208. [CrossRef]

2. Holčik, J. Petromyzontiformes. In The Freshwater Fishes of Europe; Part I; Holčik, J., Ed.; AULA-Verlag: Wiesbaden, Germany, 1986; Volume 1, pp. 119-142.

3. Kucheryavyy, A.V.; Tsimbalov, I.; Alexeevna Kirillova, E.; Nazarov, D.Y.; Pavlov, D. The need for a new taxonomy for lampreys. In Jawless Fishes of the World; Orlov, A., Beamish, R., Eds.; Scholars Publication: Cambridge, UK, 2016; Volume 1, pp. $251-278$.

4. Levin, B.; Ermakov, A.; Ermakov, O.; Levina, M.; Sarycheva, O.; Sarychev, V. Ukrainian Brook Lamprey Eudontomyzon mariae (Berg): Phylogenetic position, genetic diversity, distribution, and some data on biology. In Jawless Fishes of the World; Orlov, A.M., Beamish, R., Eds.; Scholars Publication: Cambridge, UK, 2016; Volume 1.

5. Nazari, H.; Abdoli, A.; Kiabi, B.; Renaud, C.B. Biology and Conservation Status of the Caspian Lamprey in Iran: A Review. Bull. Lampetra 2017, 8, 6-32.

6. Potter, I.C.; Gill, H.S.; Renaud, C.B.; Haoucher, D. The taxonomy, phylogeny, and distribution of lampreys. In Lampreys: Biology, Conservation and Control, Volume 1; Docker, M.F., Ed.; Fish and Fisheries Series; Springer: Dordrecht, The Netherlands, 2015; Volume 37, pp. 35-74.

7. Renaud, C.B. Lampreys of the World an Annotated and Illustrated Catalogue of Lamprey Species Known to Date; FAO Species Catalogue for Fisheries Purposes No 5; FAO: Rome, Italy, 2011.

8. Tsimbalov, I.A.; Kucheryavyi, A.V.; Pavlov, D.S.; Veselov, A.E. Description of the European river lamprey Lampetra fluviatilis (L., 1758) from the Lososinka River (Onega Lake Basin). Dokl. Biol. Sci. 2015, 462, 124-127. [CrossRef] [PubMed]

9. Zanandrea, G. Recenti ricerche sulle forme "appaiate" di lamprede dell'Italia e del Danubio. Boll. Zool. 1959, 26, 545-554. [CrossRef]

10. Berg, L.S. Freshwater Fishes of the USSR and the Neighboring Countries; AN SSSR: Moscow, Russia, 1948.

11. Shashulovskii, V.A.; Ermolin, V.P. Sostav ikhtiofauny Volgogradskogo vodokhranilishcha (Composition of the ichthyofauna of the Volgograd reservoir). Vopr. Ikhtiologii 2005, 45, 324-330.

12. Ermolin, V.P. Composition of the ichthyofauna of the Saratov Reservoir. J. Ichthyol. 2010, 50, 211-215. [CrossRef]

13. Artaev, O.N.; Ermakov, A.S.; Ruchin, A.B.; Ermakov, A.O.; Levin, B.A. Rasprostranenie ukrainskoi minogi Eudontomyzon mariae (Berg, 1931) na severo-vostochnoi granitse areala (Distribution of the Ukrainian Brook Lamprey Eudontomyzon mariae (Berg, 1931) at the north-eastern border of the distribution area). Vestn. TGU 2013, 18, 2975-2978.

14. Kuznetsov, N.V.; Makkoveeva, I.I. Zhivotnyi mir Yaroslavskoi oblasti (The Animal World of the Yaroslavl Region); Yaroslavskoe Knizhnoe Izdatel'stvo: Yaroslavl, Russia, 1959.

15. Nezdolii, V.K.; Kirillov, P.I. Pokatnaya migratsiya i raspredelenie rannei molodi karpovykh ryb v rekakh Derzhe i Shoshe (Downstream migration and distribution of the early young of the cyprinid fishes in the rivers Derzha and Shosha). In Voprosy Ekologii i Morfologii Zhivotnykh; Viktorov, L.V., Ed.; TvGU: Tver, Russia, 1997; pp. 12-34.

16. Nikanorov, Y.I.; Nikanorova, E.A. Rybokhozyaistvennaya kharakteristika vodoemov verkhov'ev Volgi, Zapadnoi Dviny i Msty (Fishery characteristics of water bodies in the upper reaches of the Volga, the Zapadnaya Dvina and the Msta). In Rybnoe Khozyaistvo Kalininskoi Oblasti; Dryagin, P.A., Nikanorov, Y.I., Eds.; Moskovskii Rabochii: Kalinin, Russia, 1974 ; pp. 3-21.

17. Puzanov, I.I.; Kiparisov, G.P.; Kozlov, V.I. Zveri, Ptitsy, Gady i Ryby Gor'kovskoi Oblasti (Mammals, Birds, Reptiles and Fishes of the Gorky Region); Gor'kovskoe obl izd-vo: Gorkiy, Russia, 1942.

18. Vasil'ev, L.I. Formirovanie ikhtiofauny Rybinskogo vodokhranilishcha Soobshchenie I Izmenenie vidovogo sostava ikhtiofauny Verkhnei Volgu v pervye gody posle obrazovaniya vodokhranilishcha (Formation of the ichthyofauna of the Rybinsk Reservoir Communication I: A change of the species composition of the ichthyofauna of the Upper Volga in the first years after the formation of the reservoir). Tr. Biol. Stantsii Borok 1950, 1, 236-255.

19. Viktorov, L.V. Kratkaya istoriya izucheniya fauny, rasprostraneniya i perspektivy faunisticheskikh issledovanii vodnykh pozvonochnykh Tverskogo kraya (A short history of the study of the fauna, distribution and the prospects of the faunistic studies of aquatic invertebrates of the Tver Region). In Fauna i Ekologiya Zhivotnykh; Viktorov, L.V., Ed.; TvGU: Tver, Russia, 1992; pp. 28-56.

20. Viktorov, L.V.; Sorokin, A.S.; Pustovit, O.P.; Pustovit, O.V. Novyi vid v ikhtiofaune i novye materialy po rasprostraneniyu nekotorykh vidov ryb i kruglorotykh Tverskoi oblasti (A new species in the ichthyofauna and new materials on the distribution of several fish and cyclostome species of the Tver Region). In Voprosy Morfologii I Ekologii Zhivotnykh; Viktorov, L.V., Ed.; TvGU: Tver, Russia, 1997; pp. 137-141.

21. Kopylov, A.I. (Ed.) Ecological problems of the Upper Volga; YaGTU: Yaroslavl, Russia, 2001.

22. Yakovlev, V.N. (Ed.) Katalog Rastenii I Zhivotnykh Vodoemov Basseina Volgi (A Catalogue of Plants and Animals of the Water Bodies of the Volga Basin); ID Papanin Institute for Biology of Inland Waters; YaGTU: Yaroslavl, Russia, 2000. 
23. Slynko, Y.V.; Tereshchenko, V.G. Ryby Presnykh vod Ponto-Kaspiiskogo Basseina (raznoobrazie, Faunogenez, Dinamika Populyatsii, Mekhanizmy Adaptatsii) (Freshwater Fishes of the Ponto-Caspian Basin [Diveristy, Faunogenesis, Dynamics of Populations, Mechanisms of Adaptations]); Poligrafpress: Moscow, Russia, 2014.

24. Gerasimov, Y.V. Ryby Rybinskogo Vodokhranilishcha: Populiatsionnaya Dinamika i Ekologiya (Fish of the Rybinsk Reservoir: Population Dynamics and Ecology); Filigran: Yaroslavl, Russia, 2015.

25. Gerasimov, Y.V.; Malin, M.I.; Solomatin, Y.I.; Bazarov, M.I.; Brazhnik, S.Y. Raspredelenie i struktura rybnogo naseleniya v vodokhranilishchakh volzhskogo kaskada v 1980-e i 2010-e gg (Distribution and structure of the fish population in the reservoirs of the Volga cascade in the 1980s and the 2010s). Trudy IBVV RAN 2018, 82, 82-106.

26. Kashina, L.I.; Kuznetsov, I.N.; Pershina, A.B.; Kuchumova, N.L. Istoriya Mariinskoi Vodnoi Sistemy: Annotirovannyi Ukazatel Dokumentov GU «Gosudarstvennyi Arkhiv Vologodskoi Oblasti» (Dosovetskii Period) (The History of the Mariinskaya Water System: An Annotated Index of Documents in the State Institution "State Archive of the Vologda Region" [Pre-Soviet Period]); VGPU: Vologda, Russia, 2011.

27. Otsenka Kachestva Vody Severo-Dvinskogo vodnogo puti (rek Vologdy i Sukhony) (Assessment of Water Quality in the Severnaya Dvina Water Way [the Rivers Vologda and Sukhona]) Otchet po Vypolneniyu NIR; VGU: Vologda, Russia, 2016.

28. Shirokova, V.A.; Snytko, V.A.; Chesnov, V.M.; Frolova, N.L.; Nizovtsev, V.A.; Dmitruk, N.G.; Shirokov, R.S. Vyshnevolotskaya Vodnaya Sistema: Retrospektiva i Sovremennost' Gidrologo-Ekologicheskaya Obstanovka i Landshaftnye Izmeneniya V Raione Vodnogo Puti (Vyshnii Volochek Water System: Past and Present Hydrological-Ecological Situation and Landscape Changes in the Area of the Water Way); OOO IPP KUNA: Moscow, Russia, 2011.

29. Shirokova, V.A.; Snytko, V.A.; Nizovtsev, V.A.; Frolova, N.L.; Dmitruk, N.G.; Chesnov, V.M.; Ozerova, N.A.; Shirokov, R.S. Tikhvinskaya Vodnaya Sistema: Retrospektiva i Sovremennost' Gidrologo-Ekologicheskaya Obstanovka I Landshaftnye Izmeneniya V Raione Vodnogo Puti (Tikhvin Water System: Past and Present Hydrological-Ecological Situation and Landscape Changes in the Area of the Water Way); Akkolit: Moscow, Russia, 2013.

30. Maitland, P.S. Ecology of the River, Brook and Sea Lamprey Conserving Natura 2000 Rivers Ecology Series No 5; English Nature: Peterborough, UK, 2003.

31. Kucheryaviy, A.V.; Tsimbalov, I.A.; Nazarov, D.Y.; Pavlov, D.S. Biological characteristics of smolts of European river lamprey Lampetra fluviatilis from the Chernaya River basin (Gulf of Finland, Baltic Sea). J. Ichthyol. 2017, 57, 276-286. [CrossRef]

32. Pavlov, D.S.; Zvezdin, A.O.; Kostin, V.V.; Tsimbalov, I.A.; Kucheryavyy, A.V. Temporal characteristics of downstream migration of smolts of the European river lamprey Lampetra fluviatilis in the Chernaya River. Biol. Bull. Russ. Acad. Sci. 2017, 44, 290-295. [CrossRef]

33. Taverny, C.; Urdaci, M. Biologie, Écologie et Pêche Deslamproies Migratrices (Agnathes Amphihalins)_Première Tranche Fonctionnelle; Cemagref Bordeaux: Cestas, France, 2003; 53p.

34. Sperone, E.; Filice, M.; Giglio, G.; Leonetti, F.L.; Tripepi, S.; Imbrogno, S. New southernmost record of the European Brook Lamprey, Lampetra planeri (Bloch, 1784) (Agnatha, Petromyzontidae). Check List 2019, 15, 131-134. [CrossRef]

35. Kucheryavyi, A.V.; Tsimbalov, I.A.; Kostin, V.V.; Pavlov, D.S. Polymorphism of spawners of the resident form of European river lamprey Lampetra fluviatilis (Petromyzontidae). J. Ichthyol. 2016, 56, 744-751. [CrossRef]

36. Hume, J.B. The Evolutionary Ecology of Lampreys (Petromyzontiformes). Ph.D. Thesis, University of Glasgow, Glasgow, UK, 2013.

37. Perea, S.; Garzón, P.; González, J.L.; Almada, V.C.; Pereira, A.; Doadrio, I. New distribution data on Spanish autochtonous species of freshwater fishes. Graellsia 2011, 67, 91-102.

38. Mateus, C.S.; Alves, M.J.; Quintella, B.R.; Almeida, P.R. Three new cryptic species of the lamprey genus Lampetra Bonnaterre, 1788 (Petromyzontiformes: Petromyzontidae) from the Iberian Peninsula. Contrib. Zool. 2013, 82, 37-53. [CrossRef]

39. Lawrie, A.H. The sea lamprey in the Great Lakes. Trans. Am. Fish. Soc. 1970, 99, 766-775. [CrossRef]

40. Smith, C.L. The Inland Fishes of New York State; New York State Department of Environmental Conservation: Albany, NY, USA, 1985.

41. Dorofeev, A.A.; Tkachenko, A.A.; Shchukina, A.S.; Yakovleva, S.I.; Samkov, M.N.; Tikhomirova, L.K.; Sharkov, M.A.; Shcherbakov, A.Y.; Grechka, P.V.; Kovalev, M.N.; et al. Geografiya Tverskoi Oblasti (The Geography of the Tver Region); Tverskoi Gosudarstvennyi Universitet: Tver, Russia, 1992.

42. Konovalov, A.F.; Borisov, M.Y.; Bolotova, N.L. Distribution of new fish species along the navigable waterways in the water bodies of Vologda oblast. Russ. J. Biol. Invasions 2015, 6, 170-178. [CrossRef]

43. Rahel, F.J.; Olden, J.D. Assesting the effects of climate change on aquatic invasive species. Conserv. Biol. 2008, 22, 521-533. [CrossRef]

44. Bolotova, N.L.; Konovalov, A.F.; Borisov, M.Y.; Dumnich, N.V. Natural and anthropogenic factors of the appereance of non-native fishes in aquatic ecosystems of Vologda RegionFormation of populations of invasive fish in aquatic ecosystems of the Vologda Oblast. Russ. J. Biol. Invasions 2010, 3, 13-32.

45. Reshetnikov, Y.S. Otryad V Anguilliformes—ugreobraznye Sem 12 Anguillidae Annotirovannyi katalog kruglorotykh i ryb kontinental'nykh vod Rossii (order V Anguilliformes-eels Fam. 12 Anguillidae). In An Annotated Catalogue of Cyclostomes and Fishes of Continental Waters of Russia; Reshetnikov, Y.S., Ed.; Nauka: Moscow, Russia, 1998; pp. 53-54. 
46. Yakovlev, V.N.; Slynko, Y.V.; Kiyashko, V.I. Annotirovannyi katalog kruglorotykh i ryb vodoemov basseina Verkhnei Volgi (An annotated catalogue of cyclostomes and fishes of the Upper Volga basin). In Ekologicheskie Problemy Verkhnei Volgi (Ecological Problems of the Upper Volga); Kopylov, A.I., Ed.; YaGTU: Yaroslavl, Russia, 2001; pp. 52-69.

47. Lebedev, V.G. Ichthyocenosis of Lake Kubensky, its state and possible changes during flow regulation. In Lake Kubenskoye. Part 3; Nauka: Leningrad, Russia, 1977; pp. 127-145.

48. Anonym. Ryby reki Sukhona (Fishfauna of the Sukhona River); GosNIORKh: Vologda, Russia, 2016; 40p.

49. Great Lakes Fishery Commission. How are Sea Lampreys Controlled. Available online: http://www.glfc.org/sealamp/how. php\#trap (accessed on 18 August 2020).

50. Pravdin, I.F. Zoologicheskie Issledovaniya v Karelii za 30 let. Nauka v KFSSR za 30 let Sovetskoj vlasti; Izd. K.-F. nauchno-issl. bazy Ak. nauk SSSR.: Petrozavodsk, Russia, 1948; pp. 121-133.

51. Pavlov, D.S.; Nazarov, D.Y.; Zvezdin, A.O.; Kucheryavyi, A. Downstream migration of early larvae of the European river lamprey Lampetra fluviatilis. Dokl. Biol. Sci. 2014, 459, 344-347. [CrossRef]

52. Zvezdin, A.O.; Pavlov, D.S.; Kucheryavyy, A.V.; Tsimbalov, I.A. Experimental study of the European river lamprey, Lampetra fluviatilis (L.), migratory behavior in the period of initial dispersion of juveniles. Inland Wat. Biol. 2017, 10, 209-218. [CrossRef]

53. Quintella, B.R.; Andrade, N.O.; Espanhol, R.; Almeida, P.R. The use of PIT telemetry to study movements of ammocoetes and metamorphosing sea lampreys in river beds. J. Fish Biol. 2005, 66, 97-106. [CrossRef]

54. Natural Earth. Free Vector and Raster Map Data at 1:10 m, 1:50 m and 1:110 m Scales. Small Scale Data, 1:110 m. Cultural. Available online: https: / www.naturalearthdata.com/downloads / (accessed on 11 November 2019).

55. Lehner, B.; Verdin, K.; Jarvis, A. HydroSHEDS Technical Documentation; World Wildlife Fund US: Washington, DC, USA, 2006.

56. CEO Water Mandate. Interactive Database of the World's River Basins. Available online: http://ceowatermandate.org/riverbasins (accessed on 17 August 2020).

57. Lehner, B.; Grill, G. Global river hydrography and network routing: Baseline data and new approaches to study the world's large river systems. Hydrol. Process. 2013, 27, 2171-2186. [CrossRef]

58. Reshetnikov, Y.S. Atlas Presnovodnykh ryb Rossii (Atlas of Freshwater Fishes of Russia); Reshetnikov, Y.S., Ed.; Nauka: Moscow, Russia, 2002; Volume 1.

59. Freyhof, J. Caspiomyzon Wagneri. The IUCN Red List of Threatened Species 2010; E.T135706A4187384. Available online: https: / / www.iucnredlist.org/species/135706/4187384 (accessed on 17 August 2020).

60. Freyhof, J. Lampetra fluviatilis (Errata Version Published in 2016). The IUCN Red List of Threatened Species 2011; E.T11206A. Available online: https:/ / www.iucnredlist.org/species/11206/97805807 (accessed on 17 August 2020).

61. Freyhof, J. Eudontomyzon Mariae (Errata Version Published in 2016). The IUCN Red List of Threatened Species 2011; E.T8173A. Available online: https:/ / www.iucnredlist.org/species/8173/97802578 (accessed on 17 August 2020).

62. NatureServe. Lethenteron Camtschaticum. The IUCN Red List of Threatened Species 2013; E.T135719A. Available online: https: //www.iucnredlist.org/species/135719/18232889 (accessed on 17 August 2020).

63. The Imperia Project Davis Center for Russian and Eurasian Studies; Harvard University: Cambridge, MA, USA; Available online: http:/ / worldmap.harvard.edu/maps/886 (accessed on 17 August 2020).

64. Zaitsev, V.A. Pozvonochnye Zhivotnye Severo-Vostoka Tsentral'nogo Regiona Rossii (vidy Fauny, Chislennost' I Ee Izmeneniia) (Vertebrate Animals of the North-East of the Central Region of Russia [Species of the Fauna, Abundance and Its Changes]); KMK Press: Moscow, Russia, 2006. 